\title{
Hvordan kan sykepleiere møte pasienter og pårørende ved livets slutt?
}

Sykepleiere kan bruke en refleksjonsmodell for å få en dypere forståelse av hvordan ytre forhold kan påvirke deres åpenhet, kunnskap og vilje til å gjøre godt i utfordrende situasjoner.

Solveig Margaret Thomassen

Universitetslektor

Fakultet for sykepleie og helsevitenskap, Nord universitet, Mo i Rana

Lisbeth Nerdal

Førstelektor

Fakultet for sykepleie og helsevitenskap, Nord universitet

Palliasjon Kunnskap Viljen til å gjøre godt Sykepleierolle

\section{Hovedbudskap}

Å møte pasienter og pårørende i livets sluttfase kan være utfordrende for sykepleiere. Når pasienter og pårørende blir klar over at døden nærmer seg, kan de reagere med skam, sinne, fortvilelse, ensomhet og sorg. Ved å bruke en refleksjonsmodell får vi en dypere forståelse av hvordan ytre forhold kan påvirke sykepleierens åpenhet, kunnskap og vilje til å gjøre godt i utfordrende situasjoner. 
Hensikten med denne artikkelen er å introdusere en refleksjonsmodell som kan gi sykepleiere en dypere forståelse av tre sentrale begreper: åpenhet, kunnskap og vilje til å gjøre godt.

Vi reflekterer over hvordan de tre begrepene henger sammen, og belyser faren for at eksterne omstendigheter påvirker hvordan sykepleierne møter pasienter og pårørende ved livets slutt.

Utgangspunktet for artikkelen er en fortelling om hva en sykepleier erfarer i møte med en pasient og hans kone i livets siste dager. Det er viktig å forstå seg selv og andre i møte med pasienter og pårørende. Det er i grensesituasjoner menneskenes menneskelighet tydeligst trer frem.

I grensesituasjoner dukker det opp mange følelser, som sinne, skam, fortvilelse og sorg. Dahl og Sørensen (1) skriver at erfaringer viser at helsepersonell har vansker med å møte for eksempel sinneutbrudd på en adekvat måte. De kommer ofte på defensiven eller havner $\mathrm{i}$ argumentasjon med pasienten eller de pårørende.

\section{Hva er refleksjonsmodellen?}

Refleksjonsmodellen er utarbeidet av Bergdahl og medarbeidere (2) og inneholder følgende begreper: ytre forhold (external conditions), som kan påvirke sykepleierens evne til åpenhet, åpenhet (perceptiveness), kunnskap (knowledge) og viljen til å gjøre godt (the will to do good) $\mathrm{i}$ omsorgen.

Essay som kritisk utprøvende metode hvor man stiller spørsmål til erfaringen, kan gi større innsikt og bedre forståelse for hva sykepleiere kan stå overfor i møte med pasienter og pårørende i livets siste dager (3).

\section{Fortellingen om Line}

Line kommer på aftenvakt på sykehuset der hun begynte å arbeide for to uker siden. Hun opplever at arbeidet er spennende, og hun føler seg godt mottatt på avdelingen. Hun ser frem til informasjon om sine pasienter før aftenvakten begynner.

På rapporten får hun informasjon om at de har fått inn en ung pasient, Per, som har vært syk i bare tre uker. Han har blitt behandlet for akutt tonsillitt, som nå viser seg å være $\varnothing$ sofaguscancer med kort forventet levetid. 
Per og kona Anne er lovet at plagene hans skal lindres så godt som mulig. Line synes det er trist å høre at Per har hatt store smerter og har vært kvalm i dag, og hun ønsker å hjelpe ham. Hun får også opplysning om at Anne har vært sint i dag, og at det er vanskelig å komme i dialog med henne.

Avdelingen har den rutinen at ansvarlig sykepleier går en runde og hilser på hver enkelt pasient etter at de har fått rapport. Line merker når hun begynner å gå runden at hun gruer seg til å møte Per og Anne.

\section{Line møtes med sinne}

Line kjenner et sug i magen idet hun banker på og skal til å åpne døren. I det samme rives døren opp fra innsiden. Line og Anne blir stående ansikt til ansikt, og Line kan kjenne raseriet som møter henne. Ansiktet til Anne er rødmusset, og hun roper høyt med sint stemme mot Line:

«Hvorfor er mannen min kvalm, han har ikke spist noe, han skal ikke være kvalm da! Og hvorfor ligger det kladder og andre sykehusting inne på rommet, det skal ikke være her.»

Line venter på at Anne skal bli ferdig, slik at hun kan få fortalt henne at hun kan hjelpe til, både med smertene og kvalmen, men kommer ikke så langt.

Anne smeller døren igjen foran Line, og opplevelsen av å være uønsket er stor. Hun venter litt utenfor $d \varnothing$ ren før hun går videre til de andre pasientene, samtidig tenker hun at hun skulle ventet med å gå inn til dem til de tok kontakt.

\section{Line møter Anne med stillhet}

En kort stund etterpå ringer klokken på rommet til Per. Line går mot rommet og banker forsiktig på døren. Hun venter litt, men ingen kommer, så hun åpner døren forsiktig og går inn.

Det er stille i rommet, Anne sitter i en stol og ser trist ut. Line går bort til henne, setter seg i stolen ved siden av og legger forsiktig hånden sin på hennes. Line er usikker på hvordan Anne vil reagere. Slik sitter de en liten stund, i stillhet.

Line begynner å fortelle Anne om hvorfor Per er kvalm, selv om han ikke har spist, og hvorfor det ligger ekstra med kladder og annet utstyr inne på rommet. Hun forklarer at hun nå vil hente medisiner for å lindre Pers smerte og kvalme.

Etter å ha gitt Per antiemetikum og smertestillende rydder Line på rommet samtidig som hun småsnakker med ham. Anne benytter anledningen å forlate rommet for å hente seg kaffe. Per forteller at han er bekymret for Anne, og at han ikke tør å vise hvor ille han har det. 
Smertene som skulle lindres, skremmer Anne. Får ikke Per nok smertelindring, slik de var lovet? Line tenker at Anne trenger informasjon om Pers sykdom og hva som kan forventes i livets siste dager.

Etter en stund er Per rolig og avslappet. Anne komme inn og setter seg ved siden av sengen med en kaffekopp mens tårene renner. Line setter seg ved Annes side, er stille og bare er der. Etter en stund sier Anne følgende: «Du kan gå nå, vi vil hvile.»

Idet Line går, sier hun: «Dersom han fremdeles opplever smerte eller blir kvalm, håper jeg du sier fra.» «Det kan du være sikker på», er svaret hun får, men stemmen til Anne er ikke lenger sint. Den er preget av gråt som har fastnet, den er fortvilet, angstfylt, livredd og preget av bunnløs sorg.

\section{Sykepleieren må ha reflekterende holdning}

Bergdahl og medarbeidere (2) mener at det er viktige forbindelser mellom elementene åpenhet, kunnskap og viljen til å gjøre godt. Disse tre elementene må være til stede for å skape en god relasjon til pasienten og de pårørende, slik at sykepleieren kan gi god personsentrert palliativ omsorg (figur 1).

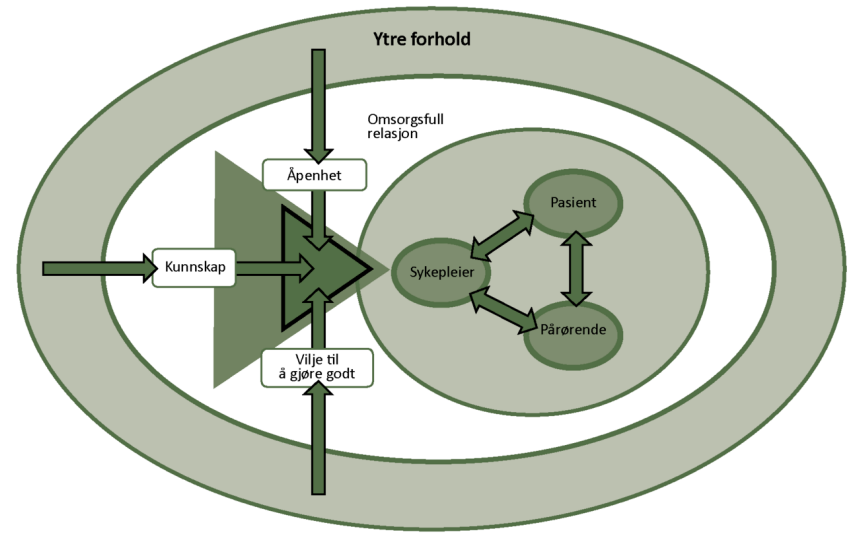

Ytre forhold kan påvirke sykepleiernes mulighet til å danne en omsorgsfull relasjon. Kilde: Bergdahl E, Benzein E, Ternestedt BM, Andershed B (2). Gjengitt med tillatelse.

Bergdahl og medarbeidere (4) beskriver at åpenhet kan tolkes på to ulike måter. Den første tolkningen er at sykepleieren må være åpen for at pasienter og pårørende er forskjellige, og at de ikke vil reagere likt i livets siste sluttfase. 
Det andre er å være tilgjengelig for og forståelsesfull overfor pasienten og de pårørende og kunne se den unike personen og ikke kun være opptatt av den kaotiske situasjonen.

Samtidig må sykepleieren intuitivt vite når hun eller han skal nærme seg, eller la pasienten og pårørende være i fred.

Sykepleierens evne til å lytte, gi oppmerksomhet og vise følelser er også viktig, det samme er en åpen og reflekterende holdning. Ifølge Bergdahl og medarbeidere (2) er det med våre følelser, vår kunnskap og vår åpenhet vi orienterer oss, lager vårt omdømme, tar beslutninger og handler i omsorgssituasjoner uten å være dominerende.

\section{Ytre forhold kan true åpenheten}

Eksterne omstendigheter kan ses på som ytre forhold som truer åpenheten (5). Det som i fortellingen kan ses som ytre forhold, er kulturen på avdelingen eller regelen om at alle sykepleiere i begynnelsen av vakten alltid skal gå rundt og hilse på pasientene.

Da Line fikk informasjon om at Anne viste sinne, tenkte hun at dette er en familie som nå er truet på livet, en familie som trenger omsorg og tilstedeværelse. Hun ønsket å kunne være til hjelp for både Anne og Per, men samtidig begynte hun å grue seg til å møte dem.

Var det de etablerte rutinene på avdelingen som påvirket hennes evne til å være åpen mot seg selv? Line vurderte at hun burde ha ventet med å gå inn til paret fordi Anne nylig hadde vært sint på en annen sykepleier. Likevel valgte hun å gå den faste runden, slik rutinen er på avdelingen.

Var det et ønske om å tilpasse seg avdelingens rutiner, et $\varnothing$ nske om å komme inn i avdelingens pleiekultur? Pleiekulturen er det faglige fellesskapet der faglige og personlige verdier og normer er vevd tett sammen (6).

Eksterne forhold kan også være knyttet til hvor lang tid det er avsatt til rapport, og hvor mye av det som har skjedd med pasienten og de pårørende i løpet av vakten, man velger å presentere. Ifølge Ranheim (7) er hver pasient unik, og det blir derfor viktig for sykepleieren å få all nødvendig informasjon. 


\section{Ytre forhold kan gi etisk konflikt}

Hvorfor ba ikke Line om flere opplysninger fra sykepleieren som ga rapport? Hva det var som utløste sinnet? Hadde det hendt noe spesielt? Var Annes uttrykk for sinne berettiget? Dahl og Sørensen (1) mener det er viktig å skille mellom berettiget eller uberettiget sine.

Berettiget sinne knytter seg gjerne til situasjoner der helsepersonell gjør feil, eller når det er systemfeil slik at prøvesvar ikke foreligger, journalen er forsvunnet eller pasienten har fått feil tid til unders $\varnothing$ kelse.

Når sykepleieren er ny på en arbeidsplass, kan det ta tid før hun eller han har funnet sin plass i kollegiet og blitt kjent med hvordan man diskuterer faglige utfordringer.

Er Line redd for at den som holder rapporten, skal oppleve henne som ny og uerfaren, og er det tid i rapporten til å starte denne diskusjonen? Denne travelheten, som er bestemt av avdelingens normer, regler og prioriteringer, kaller Martinsen «den vonde travelheten» (8).

Avdelingens rutiner, altså ytre forhold, setter Line i en etisk konflikt hvor det å følge rutinene får henne til å gå på akkord med det hun $\varnothing$ nsker å gjøre for Anne og Per.

De eksterne omstendighetene og avdelingens normer og rutiner hemmer Lines muligheter til å være åpen for sin første intuitive følelse av å vente med å banke på døren deres. Harstäde og medarbeidere (9) mener at evnen til åpenhet (perceptiveness) kan ses på som en kjernekompetanse for å bevare verdigheten innen palliativ omsorg.

\section{Ytre forhold kan påvirke kunnskapen}

Line lar seg påvirke av det som kommer frem i rapporten. Hun blir usikker og bestemmer seg til slutt for å følge rutinene på avdelingen i strid med hennes indre følelser for hvordan hun burde opptre i situasjonen. Kanskje handler det om at Line mangler erfaringskunnskap og teoretisk kunnskap om etisk vanskelige situasjoner?

Mangelen på kunnskap og erfaring kan derfor overskygges av en ytre norm eller kultur. Sykepleierens kunnskaper, kompetanse og ferdigheter er avgjørende for om pasienten vil føle seg trygg og ivaretatt i livets sluttfase. 
Sykepleierens praktiske erfaring bygger på teoretisk kunnskap (episteme) og praktisk kunnskap (techne), ifølge Benner (10). Sykepleierens erfaring har betydning for hvordan sykepleieren yter omsorg, og for hvilke relasjoner som skapes til pasienter og pårørende.

Dunn og medarbeidere (11) sier at jo mer erfaring sykepleiere har med døende pasienter, jo mer positiv blir opplevelsen for pasienten.

\section{Rutiner trumfet kunnskap}

Kaasa og medarbeidere (12) mener at forholdet mellom den profesjonsutøvende, pasienten og de pårørende må være forankret i solid faglig kunnskap og erfaring. Line forsto intuitivt at det var klokt å vente med å gå inn til Anne og Per til de selv ba om det. Dersom pårørende inviteres til en samtale de ikke $\varnothing$ nsker, kan det oppleves som en byrde (13).

\section{三 «Dersom pårørende inviteres til en samtale de ikke $\emptyset$ nsker, kan det oppleves som en byrde.»}

I situasjonen under rapporten var Lines åpenhet påvirket av at rutinene skulle følges, noe som igjen gjorde at hun ikke fikk brukt kunnskapen sin. Sykepleiere må være klar over sin egen kunnskap eller mangel på kunnskap i møte med pasienter og pårørende.

I tillegg må sykepleierne ha vilje til å tilegne seg den kunnskapen de trenger i omsorgssituasjonen. Forventningene til sykepleierens profesjonalitet er store. Ifølge Bergdahl og medarbeidere (4) opplever sykepleiere at rollen de har overfor palliative pasienter som den støttende og informasjonsgivende, er viktig for å trygge pasienter og pårørende.

\section{Manglende erfaring kan gi usikkerhet}

Ville møtet med Anne og Per blitt annerledes dersom Line under rapporten hadde valgt ikke å la seg påvirke av informasjon om de pårørendes sinne, men heller hatt mot til å være åpen for sin egen intuisjon og ventet med å gå inn til dem til de ringte på?

Å møte personer med en dødelig sykdom på en omsorgsfull måte krever god kjennskap til seg selv og evnen til å håndtere situasjoner som kan oppstå (1). 
Line veksler mellom å ønske å gjøre godt for pasienten og å grue seg til møtet med Anne og Per. På grunn av Lines manglende erfaring med pasienter i livets sluttfase ble det Lines engstelse som kom til uttrykk i møtet med dem.

Da Line ble møtt av Anne og sinnet hennes, forsto hun intuitivt at sinnet var berettiget, og at sinnet knyttet seg til manglende informasjon (1).

Hun forsto at dette var en pårørende som hadde det vanskelig, og ikke en som var vanskelig. Line ble forundret og stoppet opp utenfor døren, hun rettet oppmerksomheten mot Annes situasjon og skapte rom for undring.

\section{«Innfall» kan gi en annen utvei}

Martinsen (14) fremhever at oppmerksomheten sammen med en skjerpet oppfattelse av situasjonen får frem pasientens inntrykk av smerte, lidelse og livshåp. Lines tanker ble satt i gang, hun skjønte det var noe som var viktig, hun stoppet og undret seg, og hun fikk nye inntrykk, noe Martinsen (15) kaller «innfall»:

Det kan være en vanskelig situasjon sykepleieren står i som hun ikke finner ut av. Plutselig er det noe som faller henne inn, noe hun ikke har tenkt på før. Hun gjenkjenner noe i situasjonen og ser en mulig utvei. Hun våger å ta innfallet opp og arbeide med det.

Det skal mot til å åpne seg for innfallet, ta det opp og forfølge det. Å våge å forfølge innfallet kan føre til at det man i praktisk sykepleierarbeid er vant til å gjøre på en bestemt måte, kan og bør gjøres annerledes.

Line velger nå å vente til Anne eller Per ringer på. Hennes åpenhet, kunnskap og vilje til å gjøre godt er ikke lenger påvirket av rutiner, tid eller sykepleieren som ga rapport. Åpenhet betraktes også som nødvendig for å utvikle kunnskap om og relasjon til pasienten (2).

\section{Ytre forhold kan påvirke viljen til å gjøre godt}

Viljen til å gjøre godt kan ses på som et fors $\varnothing \mathrm{k}$ på å gi god omsorg. Spørsmålet er om ytre forhold kan hemme viljen til å gjøre godt. Pleie og omsorg tar tid (16). 
Tid og ressurser kan ifølge Wallerstedt (17) påvirke sykepleierens vilje til og ambisjon om å gjøre det best mulig for pasienten. Line hadde en indre følelse av å ville gjøre godt, men ble hindret dels av seg selv og sin manglende kunnskap, dels av de rådende ytre reglene og normene på avdelingen.

\title{
$\equiv$ «Sykepleierens vilje til å gjøre godt er viktig for å skape den unike og gode omsorgen.»
}

\begin{abstract}
Andershed og Ternestedt (5) mener at det er viktig at sykepleieren er åpen og sansende mot pasienter og pårørende, slik at de pårørende føler seg involvert i omsorgen for pasienten. I tillegg er sykepleierens vilje til å gjøre godt viktig for å skape den unike og gode omsorgen.
\end{abstract}

\section{Hva kunne Line gjort annerledes?}

Hvert forhold mellom pasienter og sykepleiere er unikt. Line satte seg ned sammen med Anne uten å si noe, hun viste med hele seg at hun var til stede for Anne.

Line merket at det da var lettere å forholde seg til Annes tristhet; her kunne hun trøste, stryke henne over armen eller være til stede for henne uten at hun måtte bruke store, fornuftige ord. Det var trygt og ukomplisert.

Når Anne er mottakelig for Lines omsorg, er det enklere for Line å gjøre godt for Anne. Line hadde imidlertid ingen erfaring med å møte sinte pårørende og visste ikke hvordan hun skulle forholde seg til den nye situasjonen.

\section{三 «Når Anne er mottakelig for Lines omsorg, er det enklere for Line å gjøre godt for Anne.»}

Hva kunne hun ha gjort annerledes slik at hennes ønske og vilje om å gjøre godt kom frem i møte med pasient og pårørende? Kanskje var hennes første intuitive følelse av å la paret være i fred, den egentlige viljen til å gjøre godt?

Kanskje var det slik, men denne gangen ble hennes indre vilje til å gjøre godt overskygget av ytre omstendigheter. Kanskje trengte Line mer mot til å stå imot de rådende normene, et mot som hun kan få med mer kunnskap og erfaring. 


\section{Konklusjon}

Fortellingen og refleksjonen viser tydelig at det er utfordrende for sykepleiere å møte pasienter og pårørende i sluttfasen av livet.

Ved å bruke refleksjonsmodellen kan sykepleiere få en dypere forståelse av hvordan begrepene åpenhet, kunnskap og vilje til å gjøre godt er beslektet, og hvordan ytre forhold kan virke inn på omsorgen og pleien i møte med pasient og pårørende i livets sluttfase.

Dersom en sykepleier ikke er åpen i møte med en pasient eller pårørende, kan det hende at hun eller han mister viktig og aktuell kunnskap om pasienten og pårørende i en gitt situasjon. Det vil være svært uheldig om det skjer ved livets slutt.

Åpenhet kan bidra til at sykepleieren får bedre kunnskap om pasienten, og viljen til å gjøre godt kan bidra til å skape gode omsorgsrelasjoner når livet går mot slutten. Sykepleieren må også være oppmerksom på at avdelingens pleiekultur kan påvirke sykepleierens handlinger på en negativ måte.

Artikkelen baserer seg kun på én fortelling, men vi håper likevel at en tilsynelatende liten hendelse kan gi innsikt og kunnskap.

Takk til Elisabeth Bergdahl for gode innspill og diskusjoner.

\section{Referanser}

1. Dahl AA, Sørensen T. Kreftsykdom: psykologiske og sosiale perspektiver. Oslo: Cappelen Damm Akademisk; 2016.

2. Bergdahl E, Benzein E, Ternestedt BM, Andershed B. Development of nurses' abilities to reflect on how to create good caring relationships with patients in palliative care: an action research approach. Nurs Inq. 2011;18(2):111-22.

3. Lindseth A, Norberg A. A phenomenological hermeneutical method for researching lived experience. Scand J Caring Sci. 2004;18(2):145-53.

4. Bergdahl E, Wikström BM, Andershed B. Esthetic abilities: a way to describe abilities of expert nurses in palliative home care. J Clin Nurs. 2007;16(4):752-60. 
5. Andershed B, Ternestedt BM. Development of a theoretical framework describing relatives' involvement in palliative care. J Adv Nurs. 2001;34(4):554-62.

6. Hamran T. Pleiekulturen: en utfordring til den teknologiske tenkemåten. Oslo: Gyldendal Norsk Forlag; 1991.

7. Ranheim A. Expanding caring: theory and practice intertwined in municipal elderly care. ResearchGate: 2011.

8. Martinsen K. «Vil du meg noe?»: om sårbarhet og travelhet i helsevesenets rom. I: Alsvåg H, Førland O, Frode F, red. Rom for omsorg? Bergen: Fagbokforlaget; 2014. s. 226-45.

9. Harstäde CW, Blomberg K, Benzein E, Östlund U. Dignity-conserving care actions in palliative care: an integrative review of Swedish research. Scand J Caring Sci. 2018;32(1):8-23.

10. Benner P. Fra novise til ekspert: dyktighet og styrke i klinisk sykepleiepraksis. Oslo: TANO i samarbeid med Munksgaard; 1995.

11. Dunn KS, Otten C, Stephens E. Nursing experience and the care of dying patients. Oncol Nurs Forum. 2005;32(1):97.

12. Kaasa S, Loge JH, Haugen DRF, red. Palliasjon: nordisk lærebok. 3. utg. Oslo: Gyldendal Akademisk; 2016.

13. James I. Bakom rutinerna: kunskap och omvårdnadspraxis i mänskliga gränssituationer. Örebro: Örebro Universitet; 2010.

14. Martinsen K. Samtalen, skjønnet og evidensen. Oslo: Akribe; 2005.

15. Martinsen K. Innfallet og dets betydning i liv og arbeid: metafysisk inspirerte overveielser over innfallets natur og måter å vise seg på. Klinisk Sygepleje. 2008;22(1):20-32.

16. Fonn M. Kari Martinsen: - Pleien tar den tiden den tar. Sykepleien. 2019;107(1):70-5. Tilgjengelig fra: https://sykepleien.no/2019/O2/kari-martinsen-pleien-tarden-tiden-den-tar (nedlastet 03.02.2020).

17. Wallerstedt B. Utmaningar, utsatthet och stöd i palliativ vård utanför specialistenheter. Örebro: Örebro universitet; 2012. 
